\title{
Synthesis and Characterization of a Phosphonated Graft Copolyimide
}

\author{
Nathinee Srinate $^{1, \mathrm{a}}$, Supakanok Thongyai ${ }^{1, \mathrm{~b}}$, Piyasan Praserthdam ${ }^{1, \mathrm{c}}$, and Robert A. Weiss ${ }^{2}$ \\ 1 Center of Excellence on Catalysis and Catalytic Reaction Engineering, Department of Chemical \\ Engineering, Faculty of Engineering, Chulalongkorn University, Bangkok 10330, Thailand \\ 2 University of Akron, Department of Polymer Engineering, 250 South Forge Street, Akron, OH 44325- \\ 0301, USA \\ E-mail: anathinee.srinate@gmail.com, btsupakanok@gmail.com (Corresponding author)
}

\begin{abstract}
A new synthesis route of phosphonated multi-block, branched copolyimide is proposed in this research. The synthesis and characterization of the series of new phosphonated graft copolyimides were prepared by combination of one-step high temperature polymerization and phosphonation method by lithiation and reaction with excess diethylchlorophosphate. The phosphonate ester product was converted to the phosphonic acid by hydrolysis. A branched polyimide structure was achieved by coupling the two polyimides with 3, 3'-diaminobenzidine. A phosphonated branched copolyimide with $32 \% \mathrm{~mol}$ phosphonation exhibited high thermal stability, with a decomposition temperature in nitrogen of $\sim 475^{\circ} \mathrm{C}$. Proton exchange membranes prepared from these copolyimides had proton conductivity of $0.02-0.03 \mathrm{~S} / \mathrm{cm}$ at $100 \%$ humidity over a temperature range of $40-100^{\circ} \mathrm{C}$.
\end{abstract}

Keywords: Copolyimide, phosphonic acid, PEM fuel cell.

ENGINEERING JOURNAL Volume 18 Issue 1

Received 5 April 2013

Accepted 13 June 2013

Published 14 January 2014

Online at http://www.engj.org/

DOI:10.4186/ ej.2014.18.1.119 


\section{Introduction}

Renewed interest in hydrogen fuel cells during the last decade has led to increased research of ionomers. Despite the large research activity directed at development of ionomers for proton exchange membranes (PEMs), there is still no suitable polymeric material for use in fuel cells at elevated temperatures, e.g., between $100^{\circ} \mathrm{C}-120^{\circ} \mathrm{C}$, which is desirable for transportation applications. Most membranes lose water above $100^{\circ} \mathrm{C}$, which decreases the proton conductivity. Blends and composite membranes have shown some improvement in conductivity above $100^{\circ} \mathrm{C}$, but, in general, single ion materials do not retain sufficient amounts of water at such temperatures to provide sufficient conductivity.

Historically, the acid functionalities used in ionomers for PEMs have been primarily carboxylic and sulfonic acids. Sulfonated polyimides have excellent thermal, oxidative stability and mechanical properties. Many works reported the advantages and disadvantages of polyimide membranes. The normal fivemembered ring in phthalic polyimides showed poor hydrolytic stability under the strongly acidic conditions of fuel cell $[1,2]$. In comparison, the six-membered ring in naphthalic polyimides displayed better thermal and chemical stability, along with improved mechanical strength than phthalic polyimides. Although their properties are excellent, napthalic polyimides are more difficult to synthesize and cast into membrane because of their low solubility in common organic solvents [3].

Phosphonic acid-containing ionomers have been much less studied than carboxylate and sulfonate ionomers [4] Early work on phosphonated polyolefin ionomers was done in 1970-1980 using a chlorphosphonylation reaction [5-10]. More recently, Emery and Savignac reviewed the synthesis of phosphonates by nucleophilic substitution of phosphorus using organolithium compounds, which minimizes the formation of side products [11]. Lafitte and Jannasch [12] phosphonated polysulfone up to $50 \%$ by lithiation. Direct lithiation in the presence of diphenyl or diethyl chlorophosphate led to the phosphonation of the biphenyl sulfone segment, while lithiation following bromination of the polymer produced phosphonation of the bisphenol A groups. Those authors [13] also made phosphonated polysulfone by lithiating the polymer, reacting it with methyl iodobenzoates and then running a $\mathrm{CuBr}$ mediated cross-coupling reaction between the iodinated polymer and [(diethyoxyphosphinyl)difluoromethyl $\mathrm{ZnBr}$. The product was dealkylated with bromotrimethylsilane to produce the phosphonic acid group.

In addition to the choice of acid groups, the microstructure of the polymer also affects the properties of PEMs, and various different chain architectures and/or morphologies have been considered for PEMs. These include block copolymers composed of hydrophobic and hydrophilic domains[14], the latter promoted proton transfer; Graft-block copolymers, e.g., poly(sodium styrene sulfonate) grafted to a polystyrene backbone, exhibited higher proton conductivity than a random copolymer with the same composition [15]. Lee et al. [11] prepared sulfoalkyated graft polyimides and found that the ionomers with the longest side chains had the best durability and chemical resistance. Cheng et al. [16] reported that sulfonated polyimides prepared from 4,4'-ketone dinaphthalene 1,1' and 8,8'-tetracarboxylic dianhydride had good solubility in common aprotic solvents and crosslinked membranes formed from this material exhibited good mechanical properties and water stability.

The research described above suggests that grafting hydrophilic chains onto a hydrophobic main-chain may represent the optimum approach for providing high mechahnical strength and good transport properties. This paper describes the synthesis and characterization of multi-block, branched copolyimides containing phosphonic acid groups.

\section{Experimental}

\subsection{Materials}

1,4,5,8-napthlenetetracarboxylic dianhydride (NTDA) and m-cresol were purchased from Sigma-Aldrich. Triethylamine (Et $3 \mathrm{~N}), 4,4$ '-diaminodiphenylether (4,4'-ODA), 3,3'-diaminobenzidine, aniline, n-butyllithium, diethylchlorophosphate (DECP) bromo-trimethylsilane (TMSBr) Tetrahydrofuran (THF) and 2-propanol were purchased from Acros Organics. 


\subsection{Synthesis of Polyimide Based on NTDA-ODA}

To a $250 \mathrm{~mL}$ three-neck flask, equipped with a dean stark trap and a $\mathrm{N}_{2}$ inlet and outlet, was added $6.01 \mathrm{~g}$ $(30 \mathrm{mmol})$ of 4,4'-ODA and $100 \mathrm{~mL}$ of m-cresol. After the 4,4'-ODA completely dissolved, $8.15 \mathrm{~g}$ (30.4 $\mathrm{mmol})$ of NTDA, and $1.46 \mathrm{~g}(14.4 \mathrm{mmol})$ of triethylamine were added and then stirred at $80^{\circ} \mathrm{C}$ for $4 \mathrm{~h}$, then at $180^{\circ} \mathrm{C}$ for $16 \mathrm{~h}$ and finally at $200^{\circ} \mathrm{C}$ for $4 \mathrm{~h}$. When the reaction was completed, the reaction mixture was precipitated with 2-propanol, filtered, washed with acetone and dried at $80^{\circ} \mathrm{C}$ in a vacuum oven overnight (13.10 g, 92\% yield). That product is hereafter denoted as PI-A. The reaction is shown in Fig.1 (section 2.2).

\subsection{Synthesis of Phosphonated Polyimide}

The synthesis of the phosphonated polyimide, to be used as the side-chains of the copolyimide, involved four reaction steps, see Fig. 1 (section 2.3).

Step 1: The first step was a polycondensation reaction. To a $125 \mathrm{~mL}$ three-neck flask, equipped with a dean stark trap and a $\mathrm{N}_{2}$ inlet and outlet, $2 \mathrm{~g}(10 \mathrm{mmol})$ of 2,2'-dibromo-4,4'diaminodiphenyl ether and 30 $\mathrm{mL}$ of $\mathrm{m}$-cresol were added. After the 2,2'-dibromo-4,4'diaminodiphenyl ether had completely dissolved, $2.79 \mathrm{~g}(10.4 \mathrm{mmol})$ of NTDA, and $0.88 \mathrm{~g}(8.6 \mathrm{~mol})$ of triethylamine were added and the solution was stirred at $80^{\circ} \mathrm{C}$ for $2 \mathrm{~h} .0 .02 \mathrm{~g}(0.2 \mathrm{mmol})$ of aniline was then added to the solution and the solution was stirred for another $2 \mathrm{~h}$. The polymer was imidized at high temperature by heating the reaction mixture to $180^{\circ} \mathrm{C}$ for 16 $\mathrm{h}$ and then $200^{\circ} \mathrm{C}$ for $4 \mathrm{~h}$. The $30 \mathrm{ml}$ of toluene was added during the thermal imidization step. When the reaction was complete, the polymer was precipitated with 2-propanol $(100 \mathrm{~mL})$, filtered, washed with acetone and dried overnight at $80^{\circ} \mathrm{C}$ in a vacuum oven. The polyimide product (PI-B) was a brown powder (4.53 g, 95\% yield).

Step 2: PI-B was chain-extended using 3,3'-diaminobenzidine, which has 4 reactive amine groups that can react with the anhydride end-group of the PI-B. The aniline provided a non-functional end-group to the PI-B, so that only a dimer was formed. The proper stoichiometric molar ratio of 3,3'-diaminobenzidine and PI-B and the steric hindrance of PI-B can control the reaction to occur at only 2 amines of the 3,3'diaminobenzidine. To a $100 \mathrm{~mL}$ three-neck flask, equipped with a $\mathrm{N}_{2}$ inlet and outlet, was added $0.04 \mathrm{~g}$ ( $0.18 \mathrm{mmol}) 3,3^{\prime}$-diaminobenzidine and $5 \mathrm{~mL}$ of $\mathrm{m}$-cresol. After the diaminobenzidine dissolved, $2 \mathrm{~g}(0.18$ $\mathrm{mmol}$ ) of PI-A in $25 \mathrm{~mL} \mathrm{~m}$-cresol was slowly added dropwise and stirred at $150^{\circ} \mathrm{C}$ for $6 \mathrm{~h}$. When the reaction was complete, the product (PI-C) was precipitated with 2-propanol $(100 \mathrm{~mL})$, filtered, washed with acetone and dried overnight at $80^{\circ} \mathrm{C}$ in a vacuum oven. PI-C was a dark brown powder (1.53 g, $75 \%$ yield).

Step 3: PI-C was phosphonated using a $100 \mathrm{~mL}$ three-neck flask, equipped with a N2 inlet and outlet. A $1 \%$ solution of PI-B $(1 \mathrm{~g}, 4.45 \mathrm{mmol})$ in THF $(110 \mathrm{ml})$ was cooled to $-78^{\circ} \mathrm{C}$ using a dry ice $/ 2$-propanol mixture. Desired n-BuLi was slowly added and stirred for $30 \mathrm{~min}$. Then, a 200\% molar excess amount of diethylcholophosphate (DECP) was quickly added and stirred for $3 \mathrm{~h}$. The reaction was terminated with 2 $\mathrm{mL} 2$-propanol and the product (PEPI-C) was precipitated in 2-propanol $(100 \mathrm{~mL})$, filtered, washed with acetone and dried overnight at $80^{\circ} \mathrm{C}$ in a vacuum oven $(0.67 \mathrm{~g}, 67 \%$ yield $)$.

Step 4: The PEPI-C was converted to the phosphonic acid derivative by suspending in THF $(1 \mathrm{~g} / 20$ $\mathrm{mL}$ ) adding a 5\% excess of bromotrimethylsilane and mixing the solution at room temperature for $24 \mathrm{~h}$. The reaction mixture was then added to a $50 \% \mathrm{HCl}$ solution in deionized (DI) water and stirred for $24 \mathrm{~h}$. The hydrolyzed polyimide (paPI-C) was then filtered, washed with DI water many times and dried overnight at $50^{\circ} \mathrm{C}$ in a vacuum oven.

\subsection{Synthesis of Phosphonated Graft Copolyimide}

To a $250 \mathrm{~mL}$ three-neck flask, equipped with a $\mathrm{N}_{2}$ inlet and outlet was added an equimolar amount of a PI A solution and a pa-PI-C solution solution in m-cresol and stirred at $150^{\circ} \mathrm{C}$ for $6 \mathrm{~h}$. An additional $15 \mathrm{~mL}$ of $\mathrm{m}$-cresol was added to dilute the viscous solution. A reaction between the two polymers occurred at the remaining two amines from the chain extension of PI-B step. When the reaction was complete, the product was precipitated with 2-propanol $(100 \mathrm{~mL})$, filtered, washed with acetone and dried overnight at $80^{\circ} \mathrm{C}$ in a vacuum oven. The resulting branched phosphonated graft-block copolymer, denoted as PBPI, was a dark brown powder. The reaction is shown in Fig. 1 (section 2.4). All synthesis route of phosphonated graft copolyimide from section 2.2 to 2.4 were presented in Fig. 1. 
Section 2.2
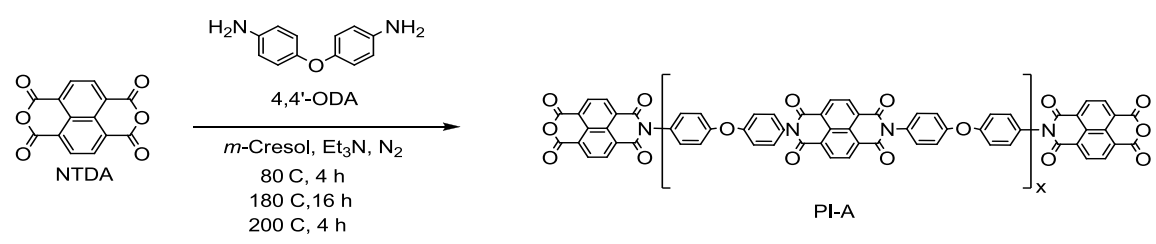

Section 2.3

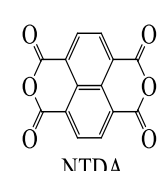

NTDA<smiles>Nc1ccc(Oc2ccc(N)cc2Br)c(Br)c1</smiles>

$\mathrm{NH}_{2}$

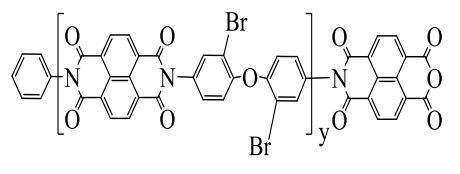

-PI-B

3) $180 \mathrm{C}, 16 \mathrm{~h}$

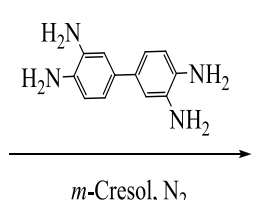

$/ 150 \mathrm{C}, 6 \mathrm{~h}$

4) $200 \mathrm{C}, 4 \mathrm{~h}$

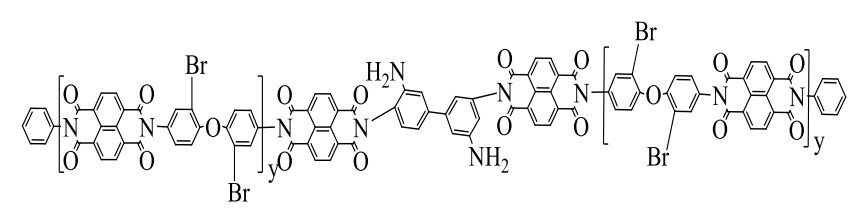

PI-C

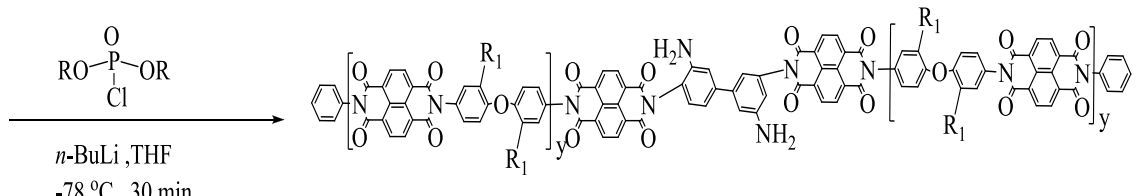

PEPI-C

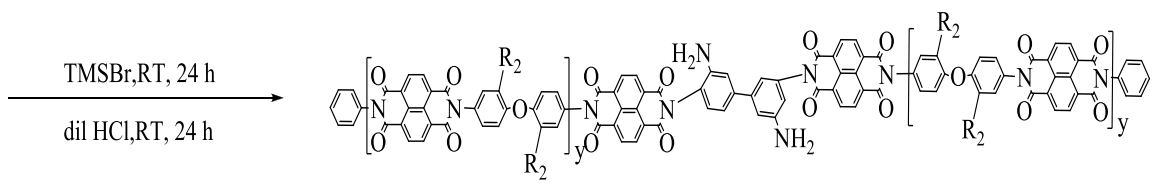

paPI-C

Section 2.4

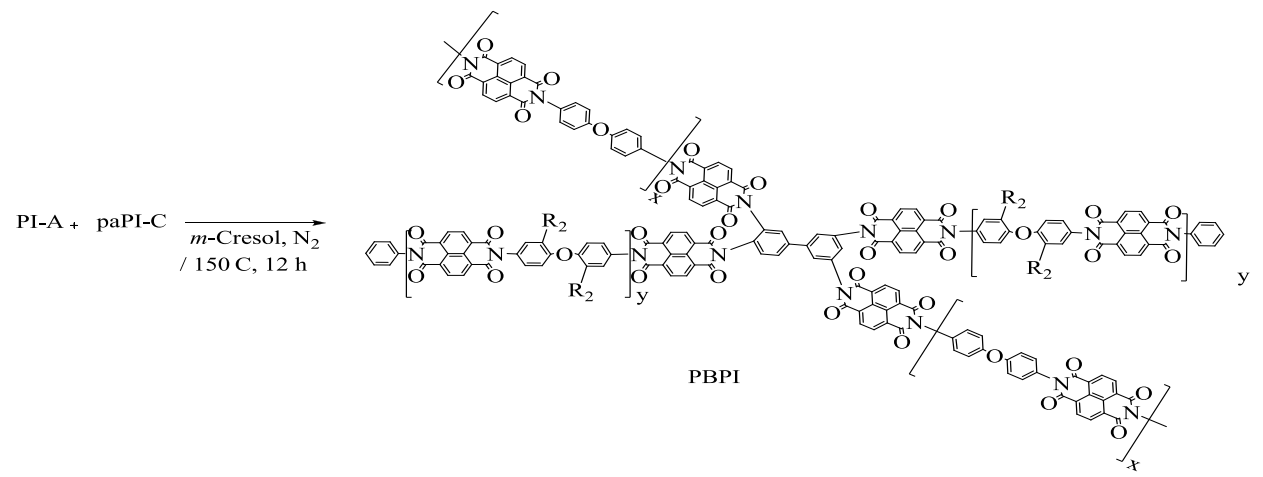

Fig.1. Synthesis Route of the phosphonated graft copolyimide described in section 2.2 to section 2.4 .

\subsection{Characterization}

Fourier transform infrared (FT-IR) spectra were obtained with a Nicolet FTIR Spectrophotometer using powder samples and a spectral range of $400-4000 \mathrm{~cm}^{-1}$. Nuclear Magnetic resonance (NMR) was performed using a Bruker 400 Ultrashield instrument, model AV400, operating at $400 \mathrm{MHz}$ and using deuterated dimethylsulfoxide (DMSO-d6) as a reference. Thermogravimetric Analysis (TGA) was used for assess the 
thermal stability of the polymers under nitrogen, using a heating rate of $20^{\circ} \mathrm{C} / \mathrm{min}$. Intrinsic viscosity measurements were conducted with a Ubbelohde viscometer using $\mathrm{m}$-cresol at $45^{\circ} \mathrm{C}$.

\subsection{Preparation of Membrane Electrode Assembly and Proton Conductivity Measurement}

The blends of PBPI and pure polyimide based on NTDA-ODA with 4:1 w/w was completely dissolved in $\mathrm{m}$-cresol at $120^{\circ} \mathrm{C}$ and cast in the clean petri-dishes, and then dried in oven at $80^{\circ} \mathrm{C}$ until the films were completely dried, yield the PBPI membranes, which had 160-180 $\mu \mathrm{m}$ thickness. Then, the film was pressed by hot-pressed at $60^{\circ} \mathrm{C}$ for 3-5 min to smooth the films.

Membrane electrode assemblies (MEAs) were prepared as follows; a $40 \mathrm{wt} \% \mathrm{Pt} / \mathrm{C}$ catalyst/Nafion ${ }^{\mathrm{TM}}$ solution from Alfa Aersa was used for preparation of the electrodes and graphite media (Sigracet $\left.{ }^{\circledR}\right)$ from Ion Power were used for the gas-diffusion layers. The $\mathrm{Pt} / \mathrm{C}$ catalyst concentration at the anode and cathode were 0.4 and $0.2 \mathrm{mg} \mathrm{Pt} / \mathrm{cm}^{2}$, respectively. The catalyst was air-brushed onto the membrane $\left(5 \mathrm{~cm}^{2}\right)$ and then hot-pressed the membrane by $120^{\circ} \mathrm{C}, 1000$ psi for $10 \mathrm{~s}$.

The experiments with MEA were kept at control condition in a humidifier for $24 \mathrm{~h}$ at room temperature and then the proton conductivities were determined with a Scribner 850e Fuel Cell Station. The $0.2 \mathrm{~L} / \mathrm{min}$ of $\mathrm{H}_{2}$ and air were fed to anode and cathode respectively. Due to short ohmic period in polarization curve of phosphonated membrane samples, the constant current at $0.2 \mathrm{~A}$ was applied for all membrane samples including Nafion@117. The Impedance spectra were recorded at $10^{-1}$ to $10^{4} \mathrm{~Hz}$ in the range between 40 and $100^{\circ} \mathrm{C}$ and at $100 \%$ humidity by setting the temperature of cathode humidifier, cell and anode humidifier to the same value (Notation $\mathrm{XX} / / \mathrm{YY} / / \mathrm{ZZ}$ refers to the temperature of cathode humidifier (XX) cell (YY) anode humidifier (ZZ)). The proton conductivity was defined as the ratio of thickness to resistance, which determined from the complex plane or Nyquist plot, and reported in units of $\mathrm{S} / \mathrm{cm}$

\section{Result and Discussion}

The structures of the polyimides were confirmed by ${ }^{1} \mathrm{H}-\mathrm{NMR}$ and FTIR. As presented in Fig. 2, the completion of the imidization step was confirmed by the absence of anhydride carbonyl peaks in the FTIR spectra in the regions around $1780 \mathrm{~cm}^{-1}$ and $1740 \mathrm{~cm}^{-1}$ and the appearance of the napthalimide carbonyl absorptions at $1710 \mathrm{~cm}^{-1}$ (asymmetric) and $1670 \mathrm{~cm}^{-1}$ (symmetric). The $\mathrm{C}-\mathrm{N}-\mathrm{C}$ vibration was observed around $1345 \mathrm{~cm}^{-1}$. In comparison with the main-chain polyimide, PI-A, PEPI-C showed three new peaks at $2980 \mathrm{~cm}^{-1}, 1030 \mathrm{~cm}^{-1}$ and $965 \mathrm{~cm}^{-1}$. The band at $2980 \mathrm{~cm}^{-1}$ was attributed to C-H stretching of ethyl group, the $1030 \mathrm{~cm}^{-1}$ band was assigned to (P)-O-C stretching and the band at $965 \mathrm{~cm}^{-1}$ was assigned to the P-O(C) vibration of the ethyl groups [17]. The absorptions arising from $(\mathrm{EtO})_{2} \mathrm{P}=\mathrm{O}$ decreased after hydrolysis, whereas the new bands between $2580-2670 \mathrm{~cm}^{-1}$ are due to $-\mathrm{P}(\mathrm{O})(\mathrm{OH})_{2}[18]$.

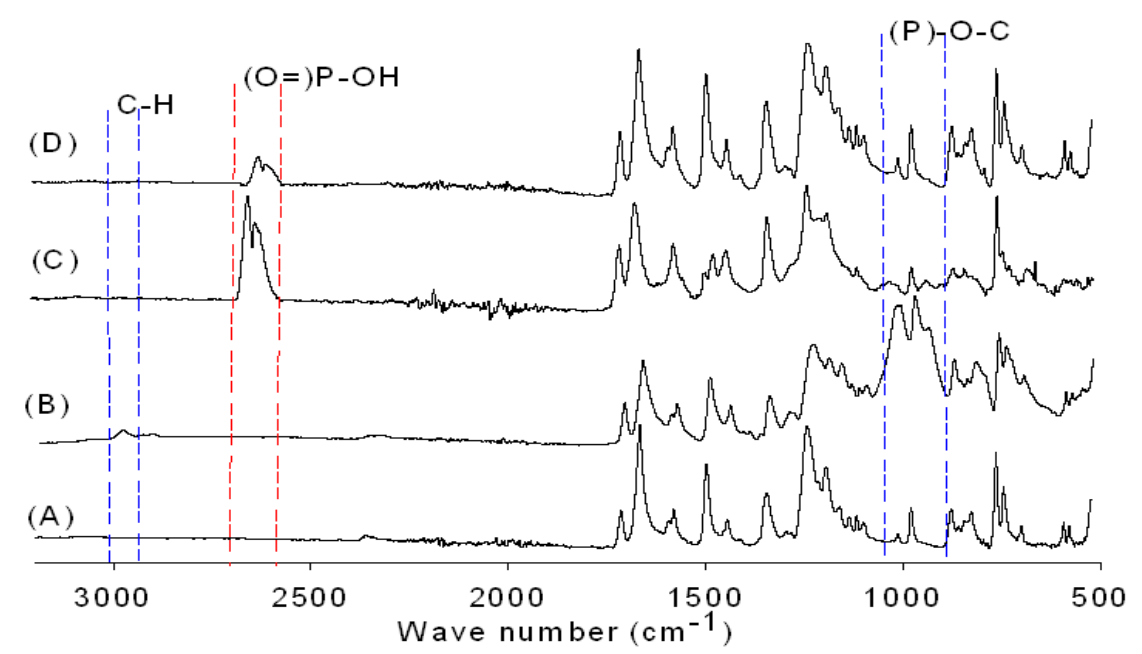

Fig. 2. FT-IR spectra of polyimide samples; (A) PI-A, (B) PEPI-C, (C) paPI-C and (D) PBPI. 
The ${ }^{1} \mathrm{H}-\mathrm{NMR}$ spectra of the PI-A polyimide, the phosphonic acid derivative of the phosphonated polyimide, paPI-C and the phosphonated graft copolyimide, PBPI was shown in poor resolution, due to the poor solubility of the polyimides in DMSO- $\mathrm{d}_{6}$. In the ${ }^{1} \mathrm{H}-\mathrm{NMR}$ spectra for the copolyimides, the formation of naphthaimide were confirmed by the chemical shifts at $8.7-8.8 \mathrm{ppm}$, which corresponded to the naphthalene protons. The remaining unreacted $-\mathrm{NH}_{2}$ groups showed up at $6.55 \mathrm{ppm}$ and the resonance of the aromatic protons in 3,3'-diaminobenzidine were at $7.54 \mathrm{ppm}$. This confirmed the chain extension of PIB. The grafting step was confirmed by the disappearance of the $-\mathrm{NH}_{2}$ resonance at $6.55 \mathrm{ppm}$.

The $\%$ phosphonation, i.e., concentration of phosphonic acid groups, was estimated from the ${ }^{1} \mathrm{H}-\mathrm{NMR}$ by calculating from the integration ratio from the sum of the integrated area of the protons of ethyl groups at $4.1 \mathrm{ppm}$ and the methyl groups at $1.29 \mathrm{ppm}$ divided by the integrated area of aromatic proton between 7.1 to $8.7 \mathrm{ppm}$ [19]. Figure 3 shows the ${ }^{1} \mathrm{H}-\mathrm{NMR}$ for PEPI-C, the phosphonate ester derivative of PI-C, for which the \%phosphonation was calculated to be $\sim 32 \%$ mol. The IEC ${ }_{n m r}$ of paPI-C calculated from ${ }^{1} \mathrm{H}-$ NMR by Eq.(1) was approximately $1.48 \mathrm{meq} / \mathrm{g}$.

where $\mathrm{X}$ is degree of polymerization.

$$
\% \text { phosphonation }=\frac{40 X}{24+20 X}
$$

The IEC of paPI-C determined from titration, was about $1.45 \mathrm{meq} / \mathrm{g}$. It can be concluded that IEC of phosphonate polyimide samples determined by titration were agreeing well with the calculation from ${ }^{1} \mathrm{H}-$ NMR of phosphonate ester derivative polyimide.

Due to the poor solubility of PBPI in DMSO- $\mathrm{d}_{6}$ solvent, the IEC of the PBPI graft copolymer was only determined by titration method which had value about $1.02 \mathrm{meq} / \mathrm{g}$. The phosphonate graft copolyimide, PBPI, had lower IEC than phosphonate polyimide samples, paPI-C. The decreases in the IEC of PBPI versus paPI-C were consistent with the dilution of the phosphonic acid groups due to the grafting of the paPI-C to the unphosphonated polyimide PI-A.

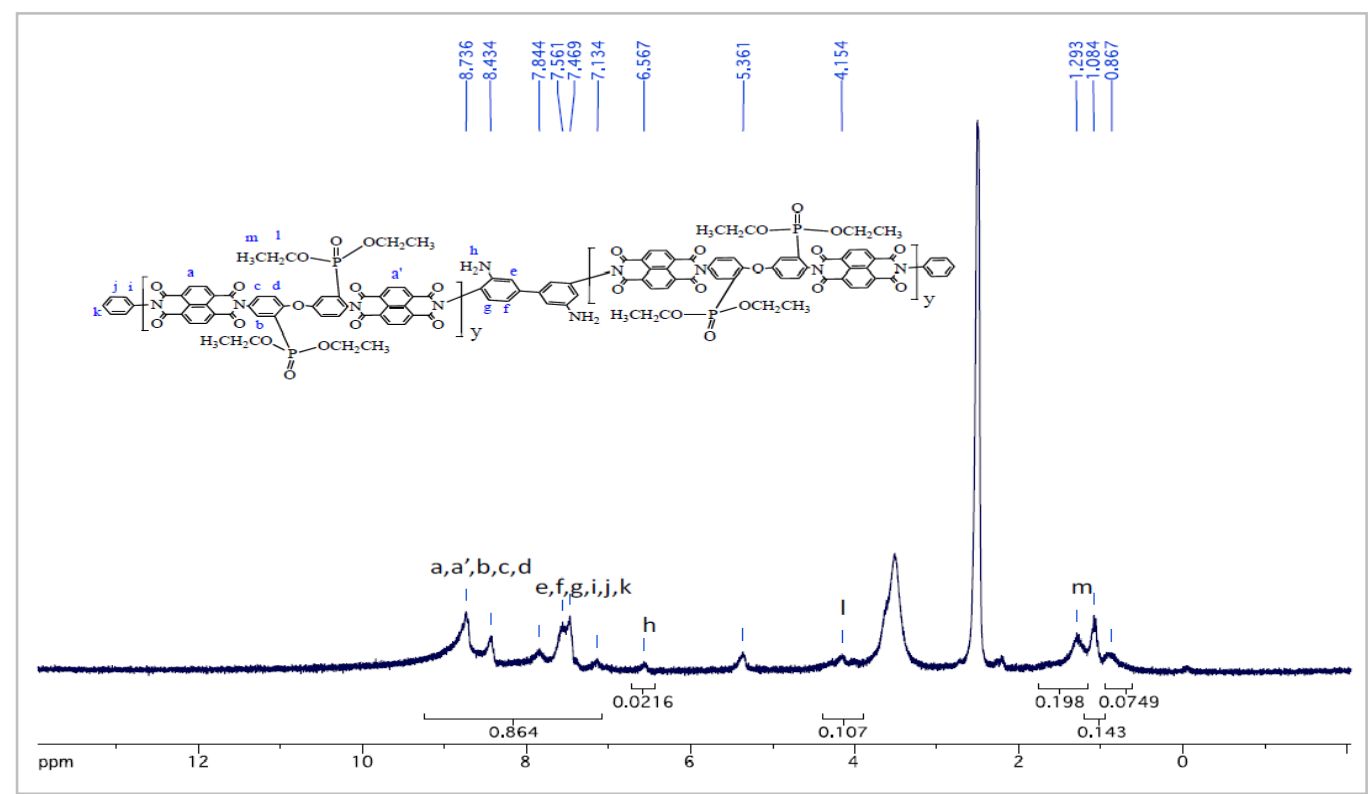

Fig. 3. $\quad{ }^{1} \mathrm{H}-\mathrm{NMR}$ of PEPI-C sample ( $32 \%$ Phosphonation $)$ in DMSO-d6.

GPC analysis was not possible for molecular weight determination, because of their poor solubility of the polymers in any solvent other than m-cresol. Viscosity average molecular weights could not be determined since no Mark-Houwink constants are available for branched polyimides described in this paper. In order to estimate the molecular weight of the graft-copolyimide, PBPI, a comparison of the intrinsic viscosities in $\mathrm{m}$-cresol at $45^{\circ} \mathrm{C}$ and the theoretical molecular weight of synthesized polymers were studied. The theoretical molecular weight was calculated based on 100\% conversion of the reactions, see Table 1 . Although the data in Table 1 cannot be used to confirm the exact structure of the PBPI, they were consistent with the grafting of paPI-C to PI-A, as shown in Fig. 1 (section 2.4). 
Table 1. Comparison of intrinsic viscosity and theoretical molecular weights of the polymides.

\begin{tabular}{cccc}
\hline Sample & $\begin{array}{c}\text { Degree of } \\
\text { polymerization }\end{array}$ & $\begin{array}{c}\text { Theoretical } \\
\mathbf{M n}^{\mathbf{a}} \\
(\mathbf{g} / \mathbf{m o l})\end{array}$ & $\begin{array}{c}{[\eta]} \\
(\mathbf{g} / \mathbf{d L})\end{array}$ \\
\hline PI-A & 149 & 33,000 & 9.30 \\
paPI-C & $49 \mathrm{~b}$ & 22,000 & 8.16 \\
PBPI & - & 55,000 & 12.48 \\
\hline
\end{tabular}

Remark a The molecular weight is calculated assuming 100\% conversion of monomers.

${ }^{\mathrm{b}}$ paPI-C was prepared from PI-B with degree of polymerization $=49$ (see Fig.1 in section 2.4).

A comparison of the thermal stability of PI-A, paPI-C and PBPI is shown in Fig. 4. All of the polymers were stable to at least $400^{\circ} \mathrm{C}$, because of the excellent stability of the imide groups. PI-A was stable to $\sim 550^{\circ} \mathrm{C}$, where degradation of the imide groups occurred. The paPI-C was less stable, probably as a result of the phosphonic acid groups. Both the paPI-C and the PBPI showed a two stage degradation process with the first mass loss occurring at about $475^{\circ} \mathrm{C}$, due most likely to degradation of the phosphonic acid groups, and a second mass loss above $570^{\circ} \mathrm{C}$ due to the degradation of the polyimide.

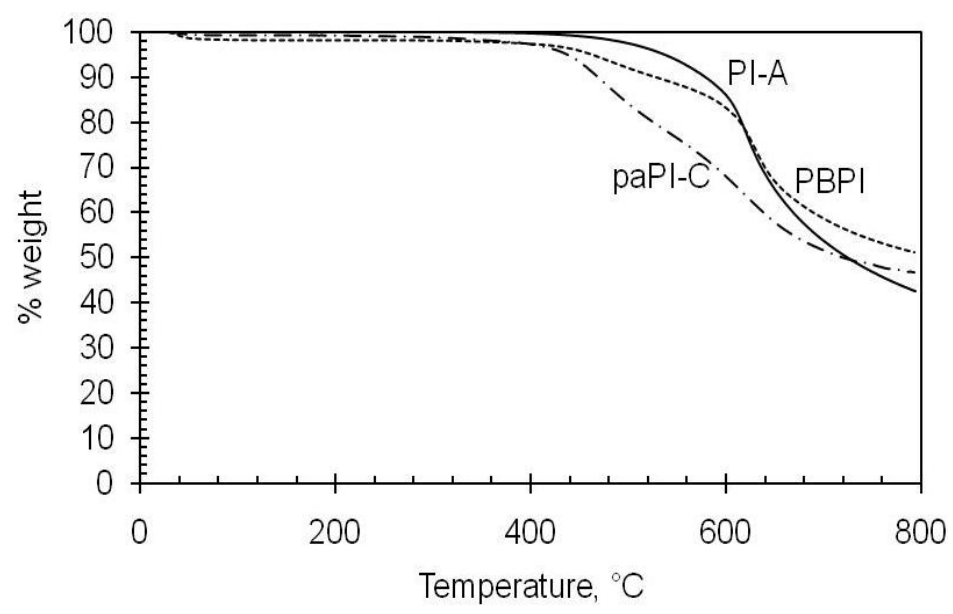

Fig. 4. TGA of the polyimides in a nitrogen atmosphere.

The phosphonated polymers also had a small mass loss below $100^{\circ} \mathrm{C}$, which was most likely water. The phosphonated polymers had higher char than the PI-A, which was not unexpected since phosphorous compounds are often used for flame retardancy, a property due to char formation that prevents the release of volatile gases and smoke during a fire. The reason for why PBPI had higher char than paPI-C, which had the highest phosphorous concentration, was not known, but may be due simply to differences in the particle sizes of the powders used for the TGA experiments. 


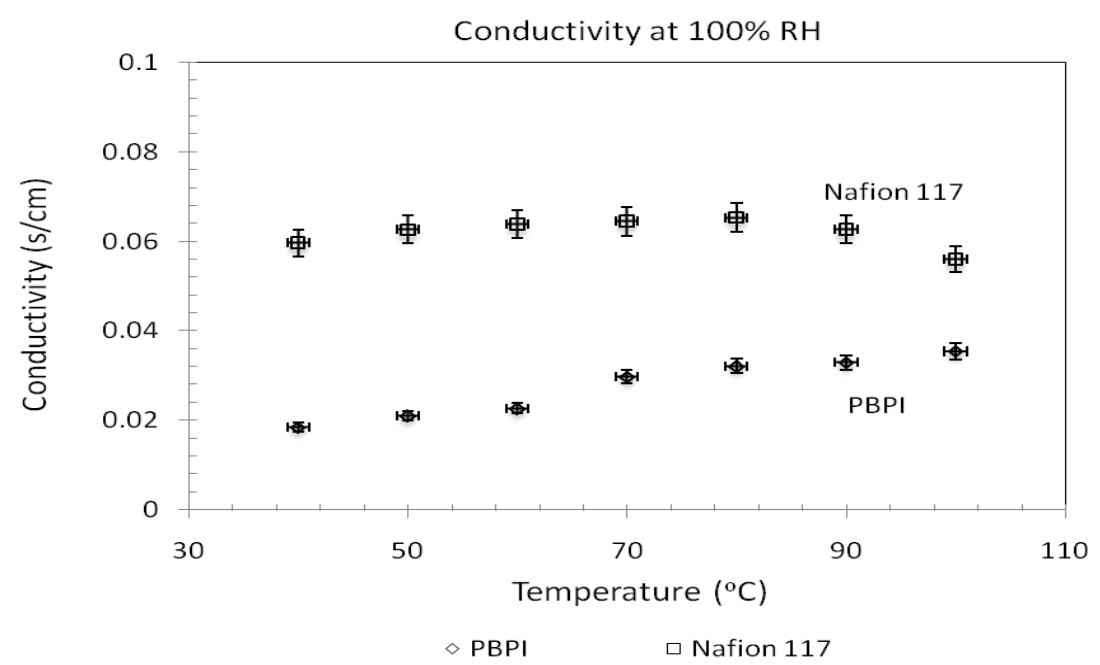

Fig. 5. Proton conductivity vs. temperature of PBPI and Nafion ${ }^{\circledR} 117$. (Remark: At $100 \%$ RH and $100^{\circ} \mathrm{C}$, the temperature of fuel cell test system was set at 98//100//98.)

The proton conductivity of PBPI membranes measured at various temperatures using $100 \%$ humidity was shown in Fig. 5. Data for Nafion ${ }^{\circledR} 117$ were also shown for comparison. The conductivity of the phosphonated polyimide membrane was comparable, though a little lower than that of Nafion ${ }^{\circledR} 117$. The conductivity of the membrane appeared to slightly increase with increasing temperature, while Nafion started to fall off at $100^{\circ} \mathrm{C}$. However, polymer blend technique was used for preparation of PBPI membrane, so if the pure PBPI were made as the membranes instead of blending, the higher proton conductivity would be attained.

\section{Conclusions}

A new phosphonated branched-block copolyimide was synthesized using a combination of polycondensation and lithiation reactions and a tetra-amine coupling compound. The synthetic route was relatively simple and allowed for facile adjustment of molecular weight of the backbone and side chains, as well as the phosphonation concentration. The phosphonated branched copolyimide was thermally stable to at least $475^{\circ} \mathrm{C}$ and membranes of the polymer had proton conductivity of $0.02-0.03 \mathrm{~S} / \mathrm{cm}$ at $100 \%$ humidity. The fuel cell performance of these membranes will be discussed in a future paper.

\section{References}

[1] B. R. Einsla, Y. T. Hong, S. Kim, F. Wang, N. Gunduz, and J. E. Mcgrath, "Sulfonated naphthalene dianhydride based polyimide copolymers for proton-exchange-membrane fuel cells. I. Monomer and copolymer synthesis," Journal of Polymer Science, Part A Polymer Chemistry, vol. 42, no. 4, pp. 862-874, 2004.

[2] B. R. Einsla, Y. S. Kim, M. A. Hickner, Y. T. Hong, M. L. Hill, B. S. Pivovar, and J. E. Mcgrath, "Sulfonated naphthalene dianhydride based polyimide copolymers for proton-exchange-membrane fuel cells II. Membrane properties and fuel cell performance," Journal of Membrane Science, vol. 255, no. 1-2, pp. 141-148, 2005.

[3] O. Savadogo, "Emerging membranes for electrochemical systems: (I) solid polymer electrolyte membranes for fuel cell systems," Journal of New Materials for Electrochemical Systems, vol. 1, no. 1, pp. 4766, 1998.

[4] R. Souzy and B. Ameduri, "Functional fluoropolymers for fuel cell membranes," Progress in Polymer Science, vol. 30, no. 6, pp.664-687, 2005.

[5] J. P. Schroder and W. P.Sopchak, "The reaction of phosphorus trichloride and oxygen with polymers," Journal of Polymer Science, vol. 47, no. 149, pp. 417-433, 1960.

[6] P. J. Phillips, F. A. Emerson, and W. J. MacKnight, "Structure and porperties of polyethylene modified with phosphonic acid side groups. I. Mechanical and thermal studies," Macromolecules, vol. 3, no. 6 , pp.767-771, 1970. 
[7] P. J. Phillips, F. A. Emerson, and W. J. MacKnight, "Structure and properties of polyethylene modified with phosphonic acid side groups. II. Dielectric properties," Macromolecules, vol. 3, no. 6, pp. 771-777, 1970.

[8] B. W. Delf and W. J. MacKnight, "Structure of some ethylene-phosphonic acid copolymers," Journal of Polymer Science: Polymer Physics, vol. 11, no. 3, pp. 571-585, 1973.

[9] R. A. Weiss, R. W. Lenz, and W. J. MacKnight, "Properties of polyethylene modified with phosphonate side groups. I. Thermal and mechanical properties," Journal of Polymer Science: Polymer Physics, vol. 15, no. 8, pp. 1409-1425, 1977.

[10] R. A. Weiss, R. W. Lenz, and W. J. MacKnight, "Phosphonate ionomers based on phosphonylated ethylene-propylene copolymer," Journal of Polymer Science: Polymer Chemistry, vol. 18, no. 9, pp. $2887-$ 2899, 1980.

[11] F. Eymery, B. Iorga and P. Savignac, "Synthesis of phosphonates by nucleophilic substitution at phosphorus: The $S_{N} P(V)$ reaction," Tetrabedron, vol. 55, no. 46, pp. 13109-13150, 1999.

[12] B. Lafitte and P. J. Jannasch "Phosphonation of polysulfones via lithiation and reaction with chlorophosphonic acid esters," Journal of Polymer Science Part A: Polymer Chemistry, vol. 43, no. 2, pp. 273 286, 2005.

[13] B. Lafitte and P. J. Jannasch, "Polysulfone ionomers functionalized with benzoyl(difluoromethylenephosphonic acid) side chains for proton-conducting fuel-cell membranes," Journal of Polymer Science Part A: Polymer Chemistry, vol. 45, no. 2, pp. 269-283, 2007.

[14] G. Maier and M. Gross, "Preparation of block polymers for PEM applications," US Patent Application, US2008027151, 2008.

[15] J. Ding, C. Chuy, and S. Holdcroft, "Enhanced conductivity in morphologically controlled proton exchange membranes: Synthesis of macromonomers by sfrp and their incorporation into graft polymers," Macromolecules, vol. 35, no. 4, pp. 1348-1355, 2002.

[16] X. Chen, Y. Yin, P. Chen, H. Kita, and K. I. Okamoto, "Synthesis and properties of novel sulfonated polyimides derived from naphthalenic dianhydride for fuel cell application," Journal of Membrane Science, vol. 313, no. 1-2, pp. 106-119, 2008.

[17] P. Chhabra and V. Choudhary, "Synthesis and characterization of sulfonated naphthalenic polyimides based on 4,4'-diaminodiphenylether-2,2'-disulfonic acid and bis[4-(4 aminophenoxy) phenylhexafluoropropane] for fuel cell applications," European Polymer Journal, vol. 45, no.5, pp. 1467-1475, 2009.

[18] G. Socrates, "Organic phosphorus compounds," in Infrared and Raman Characteristic Group Frequencies Table and Chart, $3^{\text {rd }}$ ed. West Sussex, England: John Wiley \& Sons Ltd., 2001, pp. 233.

[19] P. Sysel, M. Sochurek, and P. Holler, "Preparation of fluorine containing polymer," Polymer, vol. 39, no. 20 , pp. 4751-4755, 1998. 
